\title{
INFORMATION THREATS IN A GLOBALIZED WORLD: ECONOMICS, POLITICS, SOCIETY (EXPERIENCE OF UKRAINE)
}

\author{
Anatoliy HOLOVKA ${ }^{1}$ \\ National Institute for Strategic Studies, Ukraine
}

\begin{abstract}
The scientific article deals with both integral vision of the contemporary informative risks in the globalized world and their classification. The essence of the informative security is exposed, which is one of main factors of steady development of the modern informative society. In consideration of the foreign practice, the experience of Ukraine is also analyzed in counteraction to the contemporary informative threats. The effective policy of safety and counteraction to the informative threats is one of the basic constituents of the state national safety system and at the same time testifies to the correct character of connections between the public organs and the society. Under the conditions of unrestrained progress of information technologies and general informatization in all sectors of people's life (politics, economy, defense, energy etc.), providing of control and defense of informative space of the country becomes much more difficult task. Modern Ukrainian realities certify convincingly, that Ukraine is in an extremely difficult political situation that influences all spheres of Ukrainians' life. The key reason of such situation is a military-informative aggression against Ukraine from Russia, which is the fact of waging a «hybrid war». As it is known, this type of war combines the application of both classic soldiery instruments (military technique, firearms, regular troops) and methods of informative influence (cyber-attack, informative diversions, aggressive propaganda, impact on public opinion). This factor encourages such research. The object of the study is the phenomenon of information risks in the modern world. Subject of research - is the impact of modern information threats to the state and society, namely the economic, political and social spheres. For a holistic analysis of the subject of research was used appropriate methodology - systematic approach, method of comparative analysis, general scientific methods (analysis, synthesis, generalization, induction, deduction etc.). The article is aimed to illuminate the essence and the basic types of informative threats. The result was formulated comprehensive conclusions: First, explained the importance of understanding of informative threats, and presents their essence and classification. In addition, explained that while researching this question it is important to analyze the whole category of informative security, which is a component of the state national security. The experience of Ukraine that got into the conditions of external military-informative aggression can be an example in this context. In the study of Ukrainian realities, it is determined that modern information challenges affecting important areas of social reality.
\end{abstract}

Key words: information threats, cyber security, information security, information, society, state.

JEL Classification: O13, Z18, Y90

\section{Introduction}

The problem of counteraction to the informative threats acquired the special value in conditions of modern life, when the use of information technologies and their dynamic development is a peculiar attribute of the modern world. Besides, similar risks affect economic and financial relations, state-administrative personnel, social and political sphere, culture, social sector etc. Because of this fact, the effective safety system construction in this sphere is on the agenda of many scientific, public and business organizations, and state structures as well. For this reason, the research of this range of problems is actual. The article is aimed at illumination of the essence and the basic types of informative threats. The following tasks appear in accordance with the aim:
1) illuminations of the essence of informative threats and their classification;

2) the definition of the category «informative security»; 3) the analysis of the Ukrainian experience in counteraction to the contemporary informative threats.

The use of such methods and approaches became the methodological basis of this research:

- Systematic approach, which was used for systematization of the basic contemporary informative threats as well as a complex analysis of the informative security as an integral great number of elements and also connections between them;

- Method of comparative analysis, which was applied while studying the Ukrainian experience of counteraction

Corresponding author:

${ }^{1}$ Department of Information Security and Information Society Development, National Institute for Strategic Studies.

E-mail: tolyan-1993@ukr.net 
to the informative threats in comparing to the foreign practice;

- General scientific methods such as analysis, synthesis, generalization, induction, deduction and others.

\section{Information and information threats}

In the modern world, information technologies became the integral part of our life. They are presented in all segments: economy, politics, as well as in inner, legal and other cultural spheres. Actually, such instruments essentially improve, optimize and accelerate the man's work / the work of enterprises / of public institutions; and this fact influences positively the common development of the human civilization. Thus, the benefit and necessity of their use is undoubted today. Information in such conditions becomes a major strategic resource, a basic productive force, which provides the further development of city, region or country. That is why, like any other traditionally existent resources, information also needs a special protection.

However, it is an important fact, that the dependence of the modern society on information technologies makes it vulnerable to contemporary challenges and threats in the informative sphere. For this reason, while using the term «information» we also use such a category as «informative threats» that should be understood as the totality of all external and internal factors, which render a ruinous influence on the informative infrastructure of the state or its separate constituent, and also threaten the safety of a separately taken person or a social group (Baber, 2002).

It is worth mentioning, that the common and generally accepted classification of informative threats is absent in scientific circles today. In addition, this question is regulated in a different way in different states even at the legal level. Therefore, it is difficult to find the definite answer to the question «which threats should be referred to the informative ones »? A subjective look on the basic informative threats systematization, which exists in the modern globalized world, will be mentioned below. Thus, to the modern informative threats we can refer:

- Cyberterrorism and cybercrime;

- Distribution of unconstitutional and anti-state slogans and ideas in different information sources;

- Aggressive propaganda (both on the part of external actors and on the part of the state);

- Spreading of information directed at the exasperation of interracial / interethnic / interconfessional / interclass / interregional animosity;

- Spreading in mass media and internet of the violence cult, anti-patriotism, asocial behaviour;

- Ruinous effect on the public opinion;

- Limited access to public information by the population;

- Low level (absence) of the personal data protection;

- Low protection of the critical informative infrastructure;

- Presence of other external or internal risks, which threaten the safety of both state and social informative space.
In the view of the specific threat information can provide four main aspects of action, namely: values, technological, social, political and legal.

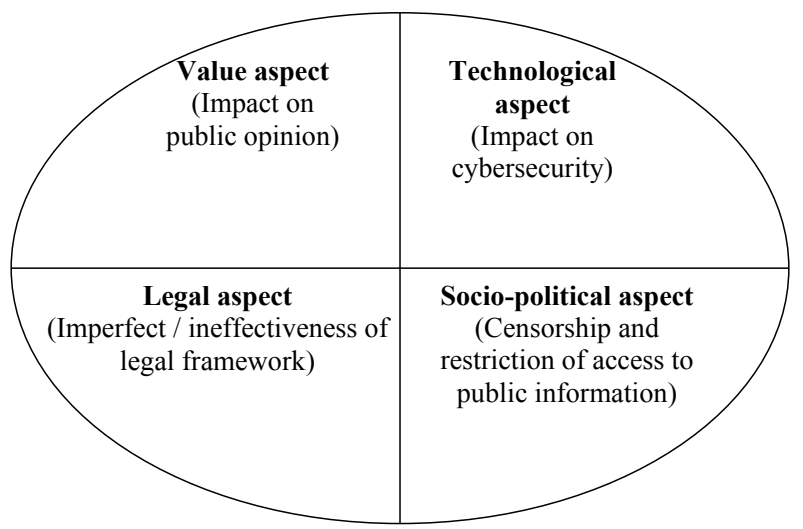

Fig. 1. Four major aspects of information threats

Obvious is the fact that such risks spread their impact on almost all social institutes, establishments and public organs of the day. The term and power of action, as well as the inflicted losses and damages (not only material) are different. Wide spectrum and the variety of informative threats determine the search for effective methods and mechanisms, which protect from the threats.

\section{Concept of information security}

While analyzing a concept of «informative threats » we cannot avoid the concept of the «informative security». In modern science and legal systems as well as in the previous case there is a problem with its exact definition. In a wide sense under informative security (it is important not to mix it up with the «safety of information») it is understood the direct condition of protecting interests of a person, a society and a state in the informative sphere.

In recent years there has been a marked increase in the importance given to matters of national security, specifically «anti-terrorist» measures by state actors. There has been a worrying trend for governments around the world to justify many contentious decisions as a response to the threat of terrorism. This terrorism emphasis has given rise to a variety of legislative measures described by their authors as a vital component in increasing the capacity of the relevant law enforcement agencies to fight the so-called «war on terror». As information and communication is just as important to perceived enemies of the state as it is to the state itself, ICT legislation is one of the targets of emphasis by governments (Carey-Smith, May 2007).

In the narrow understanding it is the condition of the protection of data handling and retention systems, where the confidentiality, the availability and the integrity of information, as well as general protection of the informative space of the country and its components (in particular of public opinion), is provided from present risks. In the conditions of an irresistible development of information technologies, we have an opportunity to observe, how 
the political influence of the state becomes scaled down and the role of the centers, which manage the informative streams, becomes scaled up.

In addition, in the context of informative security it is reasonable to remember the fact, that mass media, news agencies, television channels influence the forming of the public mind. All above-listed elements strengthened their reputation as «the fourth power». As practice (including Ukrainian) shows, it is possible to carry out a determinant influence on all spheres of the social vital activity, in particular on the political sphere, by means of such instruments. The basic subjects of informative security providing are both state structures (that carry out the activity by means of the power, determined by the current legislation) and public institutes (as their strategic allies and the participants of the national non-state security system).

An important component of information security is cyber security. Societies in today's world are becoming more and more dependent on open networks such as Internet where commercial activities, business transactions and government services are realized. This has led to the fast development of new cyber threats and information security issues, which are utilized by cyber criminals. Mistrust for telecommunications and computer network technologies have tremendous socio-economic impacts on global enterprises as well as individuals. Moreover, the occurrence of international frauds often requires the investigation of facts that occur across international borders. They are also often subject to different jurisdictions and legal systems. The increased complexity of the communication and networking infrastructure is making preventing of cyber-crimes difficult therefore new approaches for cybersecurity are desired (Szczypiorski, Mazurczyk, Janicki, 2016).

\section{Experience of Ukraine}

The beginning of the XXI century was marked by the emergence of new social and political realities of mankind. The processes of globalisation, introduction of new information technologies and formation of an information society have imparted additional importance to information security, which is an element of national security. It is the development of the information sector that will in the near future determine the political and economic role of separate states on the international stage; the ranking of countries in the information sector; and the processes of democratisation and overcoming the aftermath of totalitarianism in Ukraine. This is conditioned by the following factors.

Only timely and reliable information enables state power bodies to make balanced and well-grounded decisions; information support for domestic and foreign policies creates preconditions for their public support, and helps to form an objective image of Ukraine in the world.

At the same time, analysis of the present situation and trends in the development of the national information space shows that the level of Ukraine's information security, at least by some indicators, is reaching a critical limit (Tropical problems of Ukraine's information security, 2001).

This is primarily due to the fact that Ukraine has become an object of the military-informative pressure, which is a component part of the hybrid war strategy on the part of the Russian Federation today. As both foreign and national experience show, the state resources are usually not enough for the effective resistance to the informative blows. For this reason, the Ukrainian government and the power structures use the potential of the civil society institutes in the solution of such problems. Their help often plays a significant role in the resistance to the informative challenges, providing the effective functioning of the safety system in general. It is although impossible to ignore numerous problems that appear while attracting the civil society to the realization of the policy of the Ukrainian informative space security.

Temporary restriction on broadcasting a number of foreign TV channels cannot be considered as a sufficient measure to counter information aggression. To obtain the desired result it is necessary to create a fundamentally new system of defense of Ukraine.

Decision of former acting President Alexander Turchinov about enforcing decisions of the National Security and Defense on April 28, on measures to counter the information aggression of foreign states was important, but only a first step aimed at strengthening defense of the information space. Context Media is convinced that the

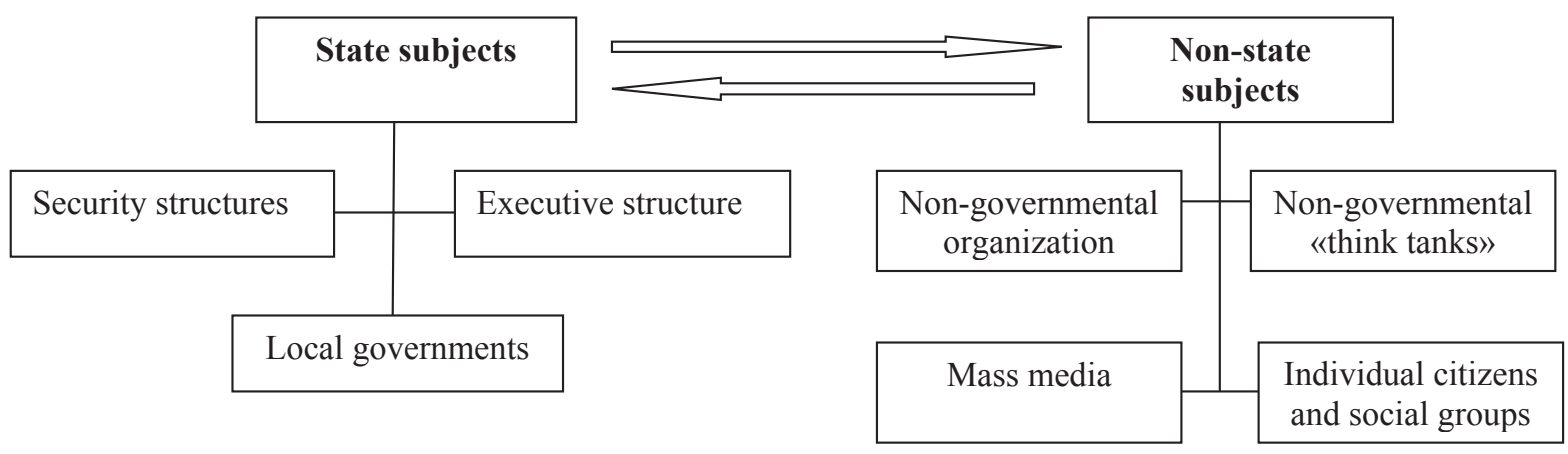

Fig. 2. Main subjects of information security 
creation of a truly efficient and effective defense is possible only in the interaction of public authorities, specialized organizations working in the information market, media, media experts, non-governmental organizations.

Using years of experience and advanced leadership positions in media monitoring and media analysis, Context Media develops and proposes effective measures aimed at strengthening the country's information security, combining them into a set of services called «Information Protection of Ukraine».

The study is conducted in the information field of the individual directions, including government agencies work and their managers, regional policy, protests, political parties and organizations, etc. There are also a variety of forms of information - from the operational notices to the monthly analytical reports containing detailed information in different directions.

For example, experts of Context Media developed a model for search and operational analysis of information for the state institutes. The proposed system requires a change in the process of collecting and analyzing data to determine timely information threats, as well as aspects affecting the reputation of Ukraine. However, implementation of the system allows maintenance of high standards of freedom of speech in the media (Information security of Ukraine, 2013).

Both in foreign countries and in Ukraine public associations, non-governmental organizations and trade unions play an important role in the realization of aims of the national security in the sphere of information. Their collaboration with the state is realized through the public councils by the state structures, by concluding treaties, even at the international level, by realization of joint projects. In this sphere, the participation of nongovernmental analytical centers and mass media is also important.

The solution of such problems as informative security and building of civil society in Ukraine is in direct connection with the increased role of the intellectual property, the development of the national informativelycommunication system as the complex of institutions, which provide the realization of the effective public informative policy, of the national informative space security, its own ideology and culture. The Ukrainian policy of the informative security providing is an important component of the policy of national security. It must be based on systematic preventive activity of the state structures in reference to the informative security granting to a person, social groups, the society and the state.

The analysis testifies that the real threats to informative security of Ukraine exist at the personal, social and state level. It is also necessary to mark that Ukrainian realities confirm the thesis that informative challenges touch all the vital functions of the society. While analyzing the contemporary practice, we can make sure of this fact once again. The main spheres of the informative risks activity are economic, political and social.
In the economic sphere, it shows up in the presence of informative diversions and blows, which are directed at doing harm to the informative infrastructure by separate industrial objects, private and state enterprises, large corporations etc. Such criminal acts are never directed to the whole system of the national economy, but have separate subjects of managing or financial institutes as their final aim. For example, numerous attempts to attack the Internet resources of the Ukrainian stock exchange. Besides, it is worth mentioning that the recent cyberattack against the corporation «Prykarpattyaoblenergo» badly influenced the work of the Ivano-Frankivsk power supply system and the power grids of other regions as well.

Regular fake reports and propaganda about mythical «death of the Ukrainian economy», «death of hryvnia» and default that must happen very soon - are also informative threats, which make a problem not only for informative, but also for economic security of Ukraine, as they influence the citizens and investors' moods. The informative factor is one of the most important in the process of forming of the national exchange rate.

In the political sphere, the force of informative risks is quicker, as they threaten to the principles of the Ukrainian national security. The informative blows from the external enemies are often directed to the undermining of the political situation in a certain region by means of confrontation of the center and the periphery. For example, the political agitation of pro-Russian forces in Donbas for the nearest beginning of the war against Kyiv, using of propaganda instruments in Odesa, Kharkiv and Dnepropetrovsk regions, informative diversions in Zakarpattia are related to the $\ll$ Ruthenian question $\gg$.

The social sphere is also a surrounding of ruinous action of informative threats. The main danger is in the use of communicatory and manipulative technologies for the exasperation of interconfessional, interclass, ethnic, interregional contradictions and conflicts. External actors (for example Russia) usually pursue this object; however, similar instruments are often popular among political parties or blocks and oligarchic clans. They use information technologies to achieve their lucrative political impulses, or to satisfy their financial interests. An example here might be the frequent media coverage of political antiadvertising, manipulation and propaganda messages, and use of «black PR» technology. This is the everyday reality in the Ukrainian political system.

Only concerted action of the current state leadership of Ukraine together with community groups can lead to achieving the desired results in the sector of information security. Addressing the cooperation between the authorities and society is important in the context of building an effective system to counter threats and risk information. This is due to the fact that the resources of the state are not enough to win the «information confrontation» with external and internal enemies. Therefore, current government partnership with social groups and associations that act as its «non-state allies» 
is necessary. All the information mentioned in the article threats can be eliminated with the active position of the Ukrainian public and government agencies wish to engage non-governmental entities to form security policy.

\section{Conclusions}

Thus, the significance of information as an important strategic resource of the state and society caused the increase of their dependence on the informative sphere condition. For this reason, in the contemporary conditions of uncontrollable development of information technologies the presence of various informative threats became an integral part of the public reality. Contemporary informative risks have a strong influence on all spheres of social life and affect the national interests as well. While researching this question it was important to analyze the whole category of informative security, which is a component of the state national security. The experience of Ukraine that got into the conditions of external military-informative aggression can be an example in this context. While setting the Ukrainian national security strategy as a «travelling map» of the general security sector reformation, the informative safety appears as its important part, which protects the national interests in the informative sphere.

The perspective of further scientific researches in this field should be mentioned. It is conditioned by a number of factors. The necessity of theoretical comprehension of such categories as «information», «informative threats», «informative security» should be mentioned as well. It is also necessary to determinate the effective mechanisms of the perfection of national informative safety system; to improve the existing effective methods of counteraction to the informative threats and to develop the new ones; to increase the efficiency of the process of citizens' attraction to the forming of the informative policy and the safety policy.

\section{References}

Carey-Smith, M., \& May, L. (2007). Information security and civil society organizations. OAI (Recent advances in security technology): p. 314-327.

Baber, Z. (2002). Engendering or Endangering Democracy? The Internet, Civil Society and Public Spher. Asian Journal of Social Science, 30(2): p. 287-303.

Szczypiorski K., Mazurczyk W. \& Janicki A. (2016). Recent Advances in Cybersecurity. Springer Open. Retrieved 26 February 2016, from: http://www.springeropen.com/collections/rac

Information security of Ukraine. (2013). Context Media. Retrieved May 2013, from: http://www.context-ua.com/ en/protection

Tropical problems of Ukraine's information security (2001). Razumkov Centre. Retrieved 2001, from: http://www.razumkov.org.ua/eng/journal_pos.php?y=2001\&cat=1\&pos=41

\section{Анатолий ГОЛОВКА}

\section{ИНФОРМАЦИОННЫЕ УГРОЗЫ В ГЛОБАЛИЗИРОВАННОМ МИРЕ: ЭКОНОМИКА, ПОЛИТИКА, ОБЩЕСТВО (ОПЫТ УКРАИНЫ)}

Аннотация. В научной статье представлены целостное видение современных информационных рисков в глобальном мире, рассмотрены их классификацию. Раскрыта сущность информационной безопасности, как одного из главных факторов устойчивого развития современного информационного общества. Также были проанализированы опыт Украины в противодействии современным информационным угрозам при учете зарубежной практики. Взвешенная и эффективная политика безопасности и противодействия информационным угрозам является одной из основных составляющих системы национальной безопасности государства и вместе с тем свидетельствует о правильном характер связей междугосударственными органами и обществом. Вусловиях безудержного прогресса информационных технологий и всеобщей информатизации всех секторов жизни человека (политики, экономики, обороны, энергетики и т. д.). Обеспечения контроля и защиты информационного пространства страны становится все более сложной задачей. Современные украинские реалии убедительно свидетельствуют, что Украина находится в крайне сложной политической ситуации, определяющим образомвлияетнавсебез исключения сферыжизниукраинскогосоциума. Ключевая причина такого положения вещей это военно-информационная агрессия против Украины со стороны России, то есть факт ведения «гибридной войны». Как известно данный тип войны сочетает в себе применение как классических военных инструментов (военной техники, огнестрельного оружия, регулярных войск), так и методов информационного воздействия (кибератаки, информационные диверсии, агрессивная пропаганда, манипуляция общественным мнением). Эти факторы и делают актуальными такие исследования. Объектом исследования является феномен информационных рисков в современном мире. Предмет исследования это влияние современных информационных угроз на государство и общество, а именно экономический, политический и социальный сегменты. Для целостного анализа предмета исследования была использована 
Vol. 2, No. 3, 2016

соответствующая методология - системный подход, метод сравнительного анализа, общенаучные методы (анализ, синтез, обобщение, индукция, дедукция и т.д.). Целью научной статьи есть исследование сущности и классификация основных типов информационных угроз. В результате были сформулированы всеобъемлющие выводы: во-первых, было объяснено важность понимания информационных угроз, а также представляет их сущность и классификация. Кроме того, обосновано идею того, что исследуя этот вопрос, важно проанализировать также категорию информационной безопасности, которая является составной частью национальной безопасности. Опыт Украины, который в условиях внешней военно-информативной агрессии послужил примером при исследовании данной проблематики. При изучении украинских реалий, было установлено, что современные информационные проблемы, сказывающиеся важные сферы социальной реальности. 